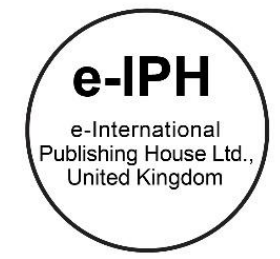

\title{
People and Urban Space in Medan: An environment behaviour approach
}

\author{
Wahyuni Zahrah*, Shella Lie \\ Department of Architecture, University of Sumatra Utara, Jl. Perpustakaan Ged.J.07 Kampus USU Medan 20155, Indonesia
}

\begin{abstract}
The paper means to explore how people use and perceive the shop house corridor as the most built environment found in Medan, Indonesia. The research observed the adaptation and or adjustment pattern of people in their built environment. The study did an interview with users of the space to get people perception of the built environment quality. The result indicates that people used space mostly for market activities, in particular for the mobile street vendor. The users make some adaptation to fit their needs. They "divided" urban space and mark their territory based on the "unwritten agreement" and tolerance.

(C) 2016. The Authors. Published for AMER ABRA by e-International Publishing House, Ltd., UK. Peer-review under responsibility of AMER (Association of Malaysian Environment-Behaviour Researchers), ABRA (Association of Behavioural Researchers on Asians) and cE-Bs (Centre for Environment-Behaviour Studies, Faculty of Architecture, Planning \& Surveying, Universiti Teknologi MARA, Malaysia.
\end{abstract}

Keywords: Urban space; built environment; environment behavior; Medan

\section{Introduction}

\subsection{Background and issues}

Indonesia has many 'unique' cities. One part of the urban image represents lifestyle and needs of the middle up income people - e.g. malls, cafes, theme parks with their sophisticated design. Meanwhile, there is another part that expresses the lowincome people needs. The space used by another class of individuals to run their lives - informal sectors, street vendors, slums, and squatters - that has poor quality. If the comfort place reflects a clean, tidy environment, attractive design and a room with air conditioning, the same features do not belong to a part of people. Finding a dirty, messy, crowded space is easy. The two contradiction - the good and the bad - configure urban impression in Indonesia, including Medan.

The most built environment that developed in Medan in the last ten years is the shop houses area. The issue of the shophouse in Malacca (Wan Ismail, 2012) and Singapore regarding the heritage conservation concern. In Medan, shop houses is a product of business growth that requires land and building efficiency. What one of the activities occur in this area is the informal sector. That kind of street vendors spread out over all city's space, from a neighborhood environment to commercial districts. From a narrow street to the large arterial road. Due to a lack of municipality's control, the informal sectors arrange the urban spaces by themselves, in their own way. The product of such 'spontaneous space' express a messy-disorder- untidy-dirty place. However, people have been living their life's at that kind of space for years. In Medan and many Indonesia's cities, the number of built

\footnotetext{
${ }^{*}$ Corresponding author. Tel.:

E-mail address: wahyuni.zahrah@gmail.com
}

(c) 2016. The Authors. Published for AMER ABRA by e-International Publishing House, Ltd., UK. Peer-review under responsibility of AMER (Association of Malaysian Environment-Behaviour Researchers), ABRA (Association of Behavioural Researchers on Asians) and cE-Bs (Centre for EnvironmentBehaviour Studies, Faculty of Architecture, Planning \& Surveying, Universiti Teknologi MARA, Malaysia.

DOI: http://dx.doi.org/10.21834/e-bpj.v1i1.235 
environment that created by this 'common' people is larger than those that designed by architects or urban designers. It can be said that such cities designed by the community. If the design activity has a noble aim to accommodate human activity, so it is necessary to understand how people create urban space. Thus, there can be a less gap between architects/designers view and the people that use it. It would give a contribution to achieving a more suitable design for local needs.

\subsection{Objective and purpose}

The research means to explore the way people use urban space, particularly in shophouses area as the most built environment developed in Medan. First, the study identifies the quality of urban space. Next, the study investigates the activities goes on, people involved, time of using and the adaptation and or adjustment of the users. The research can contribute to enriching the reference in studies about man-environment-behavior, specifically for the urban spaces that have a lack of the professional role.

\section{Literature Review}

The research is based on the theory that there are two kinds of design tradition. The first, a 'grand design' tradition that relates to the involvement of architect. The second, a 'folk tradition', that associate with primitive or vernacular people tradition. It is a fact that the built environment as a folk tradition product is larger than the grand design. Thus, that kind of design is significant in shaping built environment (Rapoport, 1969).

Altman dan Chemers (1980: 4), in their book Culture and Environment, define built environment as follow: "built environment refers to the results of people's alteration of environment - for example, homes, cities, communities, and farms. " The definition show the human alteration in changing the environment. The emphasis on human's role in the built environment also argued by Lawrence dan Low (1990). They said that built environment "refers to the broadest sense of any physical alteration of the natural environment, through construction by human ". They use the term for all environment modification by human, because "the term architecture tends to relate with a personal expert, usually monumental and becomes the civilization's nature. Thus, all built environment basically is a product of design, with or without architect (Rapoport, 1987).

A design activity is a process of choosing alternatives. The real world consists of many aspects of possibilities. People choose one of the choices to fit their needs. The option develops a 'perceived world choice'. The perceived world merges with an ideal image. The product is the built environment's expression. The difference between the perceived world, criteria and choices make a variability of environment's representation, and the quality of the environments becomes complex. The variables cannot be determined, but should be explored (Rapoport, 1980). Thus, it is necessary to search the variables because no a fix standard applied to all condition of the place and people. Every community has their own tradition. The culture influence people's perspective and practice in the urban life (Segun, 2012).

In the design process of the built environment, the action applied concerns with the perception of environment problems, the opportunity, and ideal solution, and the acceptance or neglection. The environmental perception affects how people are receiving and knowing the actual environment (Rapoport, 1980). The interaction between individual and object constructs the perception. If the contact reaches an optimum limit, the individual develops into the homeostatic condition. In this situation, the circumstance is balancing. The individual usually tends to keep this state because of its ability in improving a happy feeling. On the contrary, if the object is perceived exceed the optimum limit (e.g. too big, too cold, too strange), the individual becomes stress. The pressure becomes multiplied, so the individual has to make a 'coping' to adapt to the environment or adjust the environment to fit his or her needs. The perception scheme of Bell et al. (1978, in Sarwono, 1992) shows that the utilization of built environment depends on the individual perception. The perception causes modification, neither the adaptation - human change their behavior to match with the environment- or adjustment - people change their environment to suit their needs and behavior (Sarwono, 1992). 
1.

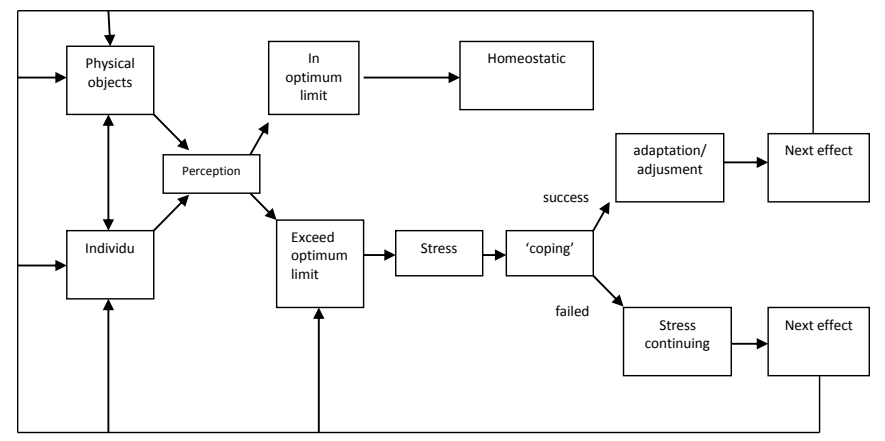

Fig.1. The perception scheme according to Bell et al (1977)

(Source: Sarwono, 1992)

\section{Methodology}

\subsection{Study location and respondents}

The study took place in a shophouses district in the center of Medan, known as "Pajak Bulan," "Pajak," in the local term, is a marketplace. The marketplace occupied the street space in Jalan Sutomo Corridor and Jalan Martinus Lubis with Jalan Sei Kera dan Jalan Seram as the boundaries (Figure 1). The respondents were 105 merchants, customers, and the local residents. The data was collected on 2014.

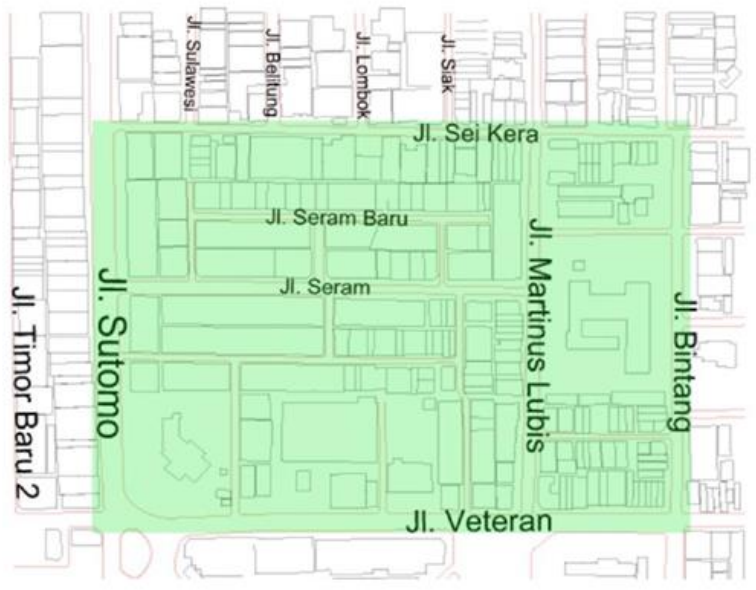

Fig. 1.The study area

\subsection{Variables and data collecting}

The research variables are the setting, activity and people perception with the setting. The setting is an urban space where people were doing their activities. The study mapped the condition of the setting by a field survey, consisted of the dimension of streetscape, accessibility, parking lot and street furniture. The study recorded the activity through behavioral mapping carried out in several time brackets: $00.00-02.00,05.00-07.00,10.00-12.00$ and15.00 -17.00 . There were two kinds of behavioral method conducted, namely person-centered mapping and place centered mapping. The person-centered mapping documented the activities chronologically. The documentation showed the step by step people occupied the urban space. The place-centered mapping observed the activity pattern in a whole study area in a time bracket. The survey collected people perception with the 
quality of space through a questionnaire. The respondents involved were those who were in the study area and agreed to participate in the study. The questionnaire consisted of the subjects about respondents background and the evaluation of the quality of space. The measuring of people perception used the five scale Likert Scale from 5 for 'excellent' to 1 for 'terrible'.

\section{Result and Discussion}

\subsection{Study area}

The shophouses corridor were located in a part of the center of commercial districts in Medan. The area has been an activity center since Dutch Colonial era. The zone consisted of shophouses typology, in Medan known as 'rumah toko' or 'ruko' in an acronym. Not far from the place, there were The Central Market of Medan. This facilities served North Sumatra province and the province surround. The study observed two corridors, namely Jalan Sutomo and Jalan Martinus Lubis (the former Jalan Bulan). The observation area was the streetscape bounded by the shophouses rows on the two sides of the corridor. This space actually was a kind of public space that functioned as a marketplace. This was not a permanent facilities since there were no permanents buildings for the market. However, this was not a temporary function since the utilization has occurred for years. The activities showed that the place was a kind of free market, but the transaction seemed like a permanent utility because of the extended time period of using. However, there were no the facilities as the general marketplace - e.g. the market kiosks, public toilets, parking lot,and the 'building' for sheltering the activities.

\subsection{Physical setting}

Jalan Sutomo and Jalan Martinus Lubis corridors were two main streets in the center of Medan. Jalan Sutomo was an arterial road connecting West and East part of Medan with 15 meters width. Jalan Martinus Lubis was a collector street with 10 meters width. The primary function of the two corridors was the circulation path, but the marketplace activities filled space in a certain time. The buildings were shop houses typology with mostly mix-use function, namely shop area on the lower level and house area in the upper level. The grid configuration of the zone made it an accessible place. The visitors could reach the corridor from all direction by many transportation modes, either public transport or private vehicle. As a street, the space seen as a long linear space. There was no pedestrian path in the corridor. The buildings front yard connected straight to the street. There was no adequate street furniture except several street lights in every 30 meters. The dust bin was tiny and could not contain the daily garbage volume.

\subsection{Utilization of urban space}

The duration of use of Jalan Sutomo for the marketplace was shorter than Jalan Martinus Lubis. This arterial corridor was busy for public use only in the midnight until early morning. The kind of transaction was a fresh market wholesale. Many kinds of vegetables sold in the area in a time range of $00.00-05.00$ early mornings. At that point, there were a slight number of vehicles passed through, except those that related to the market function. As a wholesale market, the customers were the retail merchant of traditional fresh-market around Medan. They were the frequent buyer. Even, some of them ordered the stuff by phone. Thus, the Sutomo space was more a place for picking up the order, downloading and uploading it to the vehicle box. However, for this function the street was busy. Figure 4 showed the place centered mapping in Jalan Sutomo. This space looked full of people and stuff. They occupied the entire street-space.

Figure 3 shows the person-centered mapping of a merchant in Jalan Sutomo. The picture illustrated that the merchant chose a place, marked it with his stuff, used it as a temporal territory and then the trading activity was going on. People used the urban space with no particular rule and no specific tools. They utilized the street as it was. For lighting, they brought a portable lamp. They marked the territory by their products' basket, mostly fresh vegetables. A space of $32 \mathrm{~m} 2$ was occupied by two to three merchants. There was no a 'formal" shape, such as grid composition. The merchants took the space side by side without any order. The vegetables wholesale finished at 07.00 o'clock. Then, the street normally became functioning as a circulation path. In the afternoon, at the time range of 15.00 - 17.00, the informal market again occupied Jalan Sutomo. They sold the secondary stuff, known as 'Pasar Loak' in the local term. While the wholesale took the whole street space, the secondary market took place on the sidewalk in $1-1.5 \mathrm{~m} 2$ area. They were concentrated in the conjunction Jalan Sutomo - Jalan Veteran. The urban space became crowded again because the transaction took place in a part od street space. By the absence of adequate parking lot, customers put their vehicle in the street periphery. The condition made the street so crowded and busy. People could find many 
activities utilized street space: the moving cars and other transportation modes, the cars and the other vehicles parked in the street border, the merchants, and the customers. The place centered mapping in figure 5 showed this situation.

Meanwhile, at Jalan Martinus Lubis also occurred the market activities, started from 02.00 in the early morning. In this place, people sold the fresh vegetables retail. The peak activity was going on at $05.00-07.00$ in the morning. Beside the 'free market,' the shophouse around the street also sold many kinds of foodstuff, such as rice, sugar, flour, cooking oil; all goods that complemented each other with fresh market sold on the street. This situation made the area very active and busy. Many people came here buying daily foodstuff they needed. It showed that there was a symbiosis mutualism between free market vendors and the permanent store. The facilities in the shophouses, such as the toilet, was used by the merchants.

The different of the type of transaction caused the different way in utilizing the space. In Jalan Sutomo, the merchants did not need many types of equipment, in Jalan Martinus the vendor had to provide a wood table and or an umbrella or tent for sheltering their area (Figure 3). It was because, in the retailing market, the transaction took a longer duration than the wholesale at Jalan Sutomo. In this case, the market was going on until $11.00 \mathrm{am}$. The equipment was mostly portable, so it could not change the 'original' condition of the street. However, when the market finished, the merchants left it on the street periphery. They put it in place in front of the shophouse under shophouse owner permission. The merchants entrusted it to the shophouse owner around their area and paid the cost for it. The charge for it not so expensive. At 11.00 am the market activities were becoming inactive. At $15.00 \mathrm{pm}$, the street was functioning again as a circulation path.

The users of the urban space mostly had a good perception of the security and accessibility of the place but gave the lower score for the cleanliness and facilities. With this condition, people used the corridor so intensive, neither as a marketplace and circulation path. The fact showed that the urban space was active, many people came to the place every day. Some reasons they mentioned to visit the market were the affordable commodity $(60 \%)$ and the close range from their home(23\%). In Jalan Sutomo, there were not interaction between merchants and the buildings owner around, but there was a social interaction in Jalan Martinus Lubis. Free-market merchants and the buildings owners knew each other and took a mutual relationship. From this point of view, the corridor was a success and livable community space.

These two corridors demonstrated that people assumed the urban space could be occupied by the private interest; being a marketplace in this case. In the other side, some of the urban community seems accepted this. They kept coming to the place and thought that the place supplied their needs. Thus, the street became a 'public facility'. There was no quality concern for this needs. The most important were the commodity they looked for was low-priced, and the place were accessible. This was the choice they made, the cost was the main reason. Referred to the choice model in designing built environment that proposed by Rapoprt (1980), the economical reason seemed the most motive people choose. The facilities mean the cost, but the public spaces mean a free charge.

The study indicated that people tended to maintain this situation. They survived in this condition by making the space as it was. There was no permanent adjustment. They mostly made an adaptation instead of adjustment or modification of the existing setting. They used portable equipment, they wore a coat in the rainy days and survived with this. From the environment behavior approach, they were in a homeostatic-circumstant. They subsist in this way for many years. It can be said that they were in a homeostatic state (Bell et al.,1978, in Sarwono, 1992)

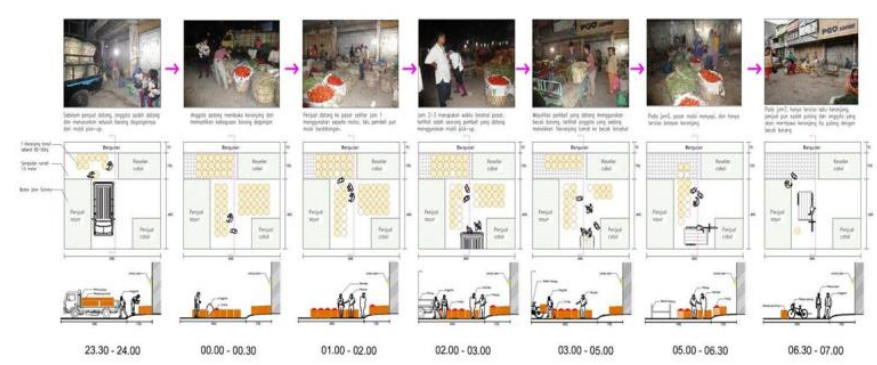

Figure 2: Person-centered mapping of utilization of urban space at Jalan Sutomo from $23.30-07.00$ 


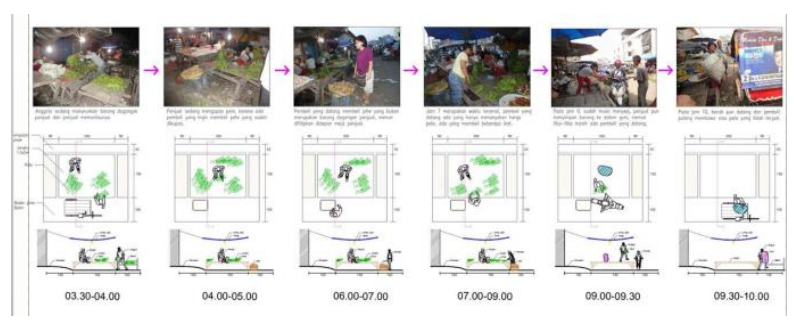

Fig. 3. Person centered mapping of urban space uses at Jalan Martinus Lubis from $03.30-10.00$

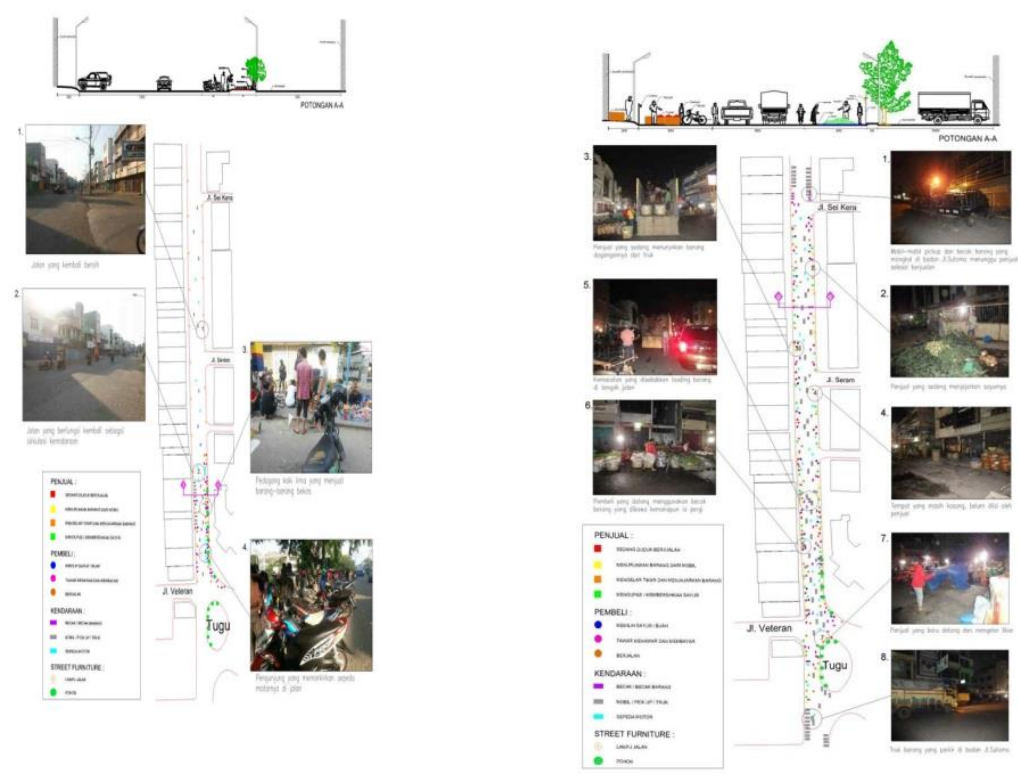

Fig. 4. Place centered mapping of activities at Jalan Sutomo at early morning (left) and afternoon (right) 


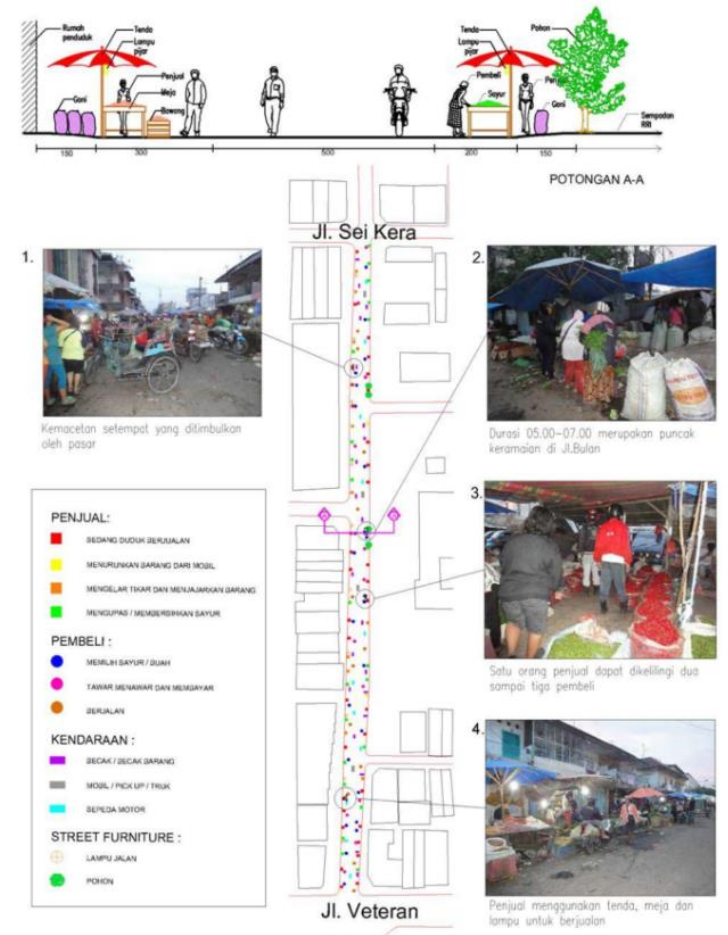

Fig. 5. Place centered mapping of activities at Jalan Martinus Lubis in the morning

\section{Conclusion}

The research showed that public space in the urban area of Medan, in this case, the shop houses area, became a private interest. However, since the place contributed to the public needs, it has been used for many years with all its limitation of quality and facility. The people seemed accepted the place. They kept coming to buy their daily needs. The process and the arrangement of the area were going on in a natural way without any professional or government role. The urban space had a poor quality but showed a dynamic atmosphere. As long as it did not cause a conflict of interest between the other people needs, this kind of space need to be enhanced, particularly the facilities (e.g. cleanliness and parking lot). However, the spread out of this 'free occupation' over the city's areas, would interfere public needs for a comfort and easy circulation path. The economic reason for occupying this kind of space should be responded by developing an affordable and well management marketplace. The government has to pay more attention to the informal sector. However, the research has a limitation in just exploring the utilization of space by people who use and have interest with the place. The next study recommended is to observe and analyze the perception of the other users, such as street and building users around the space.

\section{References}

Altman, Irwin dan Chemers, Martin, (1980). Culture and Environment, Monterey, California: Books/Cole Publishing Company.

Horayangkura, Vimolsiddhi (2012). Incorporating environment-behavior knowledge into the design process: an elusive challenge for architects in the 21st century. Procedia - Social and Behavioral Sciences 50 ( 2012 ) 30 - 41

Lawrence, Denise L. and Low, Setha M. (1990). The Built Environment and Spatial Form. Annual Review of Anthropology Vol. 19, (1990), pp. 453-505

Rapoport, Amos, (1969). House, Form and Culture, Englewood Cliffs, NJ : Prentice-Hall, Inc.

Rapoport, Amos, (1980). Human Aspect of Urban Form, Oxford: Pergamon Press.

Sarwono, Sarlito Wirawan, 1992, Psikologi Lingkungan, Jakarta : Gramedia dan Program Pascasarjana Program Studi Psikologi, Universitas Indonnesia.

Segun, Okunola (2012). Behavioral outcomes of culture and socio-economic status on urban residential morphology: a case study of Lagos, Procedia - Social and Behavioral Sciences 50 ( 2012 ) 294 - 306

Wan Ismail , Wan Hashimah, (2012). Users and the survival of the shop houses in the historic city of Malacca, Procedia - Social and Behavioral Sciences $42 .($ 2012 ) $443-450$ 